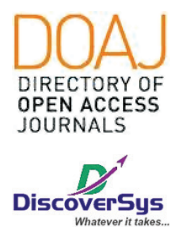

Published by DiscoverSys

\section{Pengaruh obesitas pada kualitas tidur mahasiswa Fakultas Kedokteran Universitas Udayana periode 2018}

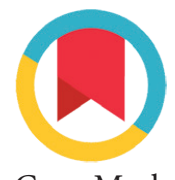

CrossMark

\author{
Yudha Anggoro Kawi, ${ }^{1 *}$ Desak Made Wihandani, ${ }^{2}$ I Wayan Surudarma ${ }^{2}$
}

\section{ABSTRACT}

Introduction: Increased obesity rates in adolescents can lead to the emergence of new risk populations for the occurrence of sleep disorders. The emergence of sleep disorders will have a direct impact on decreasing the quality of sleep. This study aims to determine the effect of obesity on the sleep quality of students of the Faculty of Medicine, Udayana University.

Method: The study design was cross sectional analytic with a total sample of 74 students of the Medical Faculty of Udayana University (37 samples of the Body Mass Index (BMI) obesity and 37 samples of the normal BMI). Sample selection is done randomly. Measuring sleep quality was done through filling in the Pittsburgh Sleep Quality Index (PSQI) questionnaire and measuring obesity was done by calculating $\mathrm{BMI}$. The answers to the questionnaire were scoring and based on the global score, sleep quality was categorized into poor and good sleep quality. The PSOI questionnaire also included questions about health problems experienced by students in the past month. Data analysis is presented in the form of tables and narratives.

Result: The results showed that in the obese student group there were 22 samples with poor sleep quality (53.7\%) and 15 samples with good sleep quality (45.5\%). In the normal IMT student group there were 19 samples with poor sleep quality (46.3\%) and 18 samples with good sleep quality (54.5\%). In 20 students with health problems, there were 15 samples with poor sleep quality and 5 samples with good sleep quality. In 54 students without health problems, 26 samples with poor sleep quality and 28 samples with good sleep quality. Analysis using chi-square showed obesity did not have a significant effect on sleep quality $(p=0.483)$. There was a significant effect of health problems on sleep quality $(p=0.039)$.

Conclusion: Conclusions of the study were obesity did not have a significant effect on the quality of sleep of students of the Faculty of Medicine, Udayana University.

Keywords: Obesity, sleep quality, PSQI, health problems.

Cite This Article: Kawi, Y.A., Wihandani, D.M., Surudarma, I.W. 2019. Pengaruh obesitas pada kualitas tidur mahasiswa Fakultas Kedokteran Universitas Udayana periode 2018. Intisari Sains Medis 10(3): 524-529. D0I: 10.15562/ism.v10i3.442

ABSTRAK

Latar Belakang: Peningkatan angka obesitas pada remaja dapat menimbulkan munculnya populasi berisiko baru untuk terjadinya gangguan tidur. Timbulnya gangguan tidur akan berdampak langsung pada penurunan kualitas tidur. Penelitian ini bertujuan untuk mengetahui pengaruh obesitas pada kualitas tidur mahasiswa Fakultas Kedokteran Universitas Udayana.

Metode: Rancangan penelitian adalah analitik cross sectional dengan total sampel sebanyak 74 mahasiswa Fakultas Kedokteran Universitas Udayana (37 sampel Indeks Massa Tubuh(IMT) obesitas dan 37 sampel IMT normal). Pemilihan sampel dilakukan secara acak. Pengukuran kualitas tidur dilakukan melalui pengisian kuisioner Pittsburgh Sleep Quality Index (PSQI) dan pengukuran obesitas dilakukan dengan perhitungan IMT. Jawaban pada kuisioner diskoring dan berdasarkan skor global, kualitas tidur dikategorikan menjadi kualitas tidur buruk dan baik. Pada kuisioner PSQI juga dilampirkan pertanyaan mengenai gangguan kesehatan yang dialami mahasiswa satu bulan terakhir. Analisis data dipaparkan dalam bentuk tabel dan narasi.
Hasil: Hasil penelitian menunjukkan pada kelompok mahasiswa obesitas terdapat 22 sampel dengan kualitas tidur buruk $(53,7 \%)$ dan 15 sampel dengan kualitas tidur baik(45,5\%). Pada kelompok mahasiswa IMT normal terdapat 19 sampel dengan kualitas tidur buruk(46,3\%) dan 18 sampel dengan kualitas tidur baik(54,5\%). Pada 20 mahasiswa dengan gangguan kesehatan, terdapat 15 sampel dengan kualitas tidur buruk dan 5 sampel dengan kualitas tidur baik. Pada 54 mahasiswa tanpa gangguan kesehatan, 26 sampel dengan kualitas tidur buruk dan 28 sampel dengan kualitas tidur baik. Analisis menggunakan chi-square menunjukkan obesitas tidak memiliki pengaruh bermakna terhadap kualitas tidur $(p=0,483)$. Terdapat pengaruh signifikan gangguan kesehatan terhadap kualitas tidur $(p=0,039)$.

Simpulan: Penelitian ini menyimpulkan obesitas tidak memiliki pengaruh signifikan terhadap kualitas tidur mahasiswa Fakultas Kedokteran Universitas Udayana.
Studi Pendidikan Dokter, Fakultas Kedokteran, Universitas Udayana, Bali-Indonesia

yudha.kawi@gmail.com
Diterima: 14-03-2019

Disetujui: 11-04-2019

Diterbitkan: 01-12-2019
Kata kunci: Obesitas, kualitas tidur, PSQI, gangguan kesehatan

Cite Pasal Ini: Kawi, Y.A., Wihandani, D.M., Surudarma, I.W. 2019. Pengaruh obesitas pada kualitas tidur mahasiswa Fakultas Kedokteran Universitas Udayana periode 2018. Intisari Sains Medis 10(3): 524-529. D0I: 10.15562/ism.v10i3.442 


\section{PENDAHULUAN}

Saat ini, obesitas adalah salah satu masalah kesehatan besar yang dihadapi dunia. Obesitas sendiri, didefiniskan sebagai keadaan penumpukan lemak yang berlebihan di dalam jaringan lemak sehingga menggangu kesehatan. ${ }^{1}$ Pada umumnya, masyarakat dibingungkan antara mana yang disebut obesitas dan overweight (kelebihan berat badan). Apabila seseorang (khususnya pada kalangan dewasa) dengan IMT 30 atau lebih, secara umum dianggap obesitas. Sementara, seseorang dengan IMT setara atau lebih dari 25, dianggap overweight (kelebihan berat badan). ${ }^{2}$

Hingga tahun 2014, World Health Organization (WHO) mencatat pada usia 18 tahun ke atas terdapat lebih dari 600 juta kasus obesitas di dunia. ${ }^{2}$ Insiden obesitas dinyatakan meningkat dua kali pada anak dan empat kali pada remaja dalam tiga puluh tahun terakhir. ${ }^{3}$ Penderita kasus obesitas sentral pada penduduk di Indonesia dengan usia 15 tahun ke atas tercatat sebesar 26\% dari penduduk Indonesia. Angka ini setara dengan 63.212.392 jiwa. Secara khusus, di provinsi Bali, terdapat 1.089.411 penderita obesitas.

Remaja adalah tempo waktu transisi antara kanak-kanak menuju dewasa. Dalam masa peralihan ini tentunya diiringi perubahan jadwal dan aktivitas kegiatan. Beberapa di antaranya jadwal di sekolah/perkuliahan yang mulai padat. Beberapa remaja ada yang sudah mulai bekerja. Di satu sisi lingkungan pergaulan yang makin luas, memicu kebiasaan berkeliling hingga larut malam. Selain itu mudahnya datang rasa jenuh dan bosan, membuat remaja suka mencari hiburan. Salah satunya menyaksikan tayangan televisi. Dan tentunya bila sudah di depan layar kaca, akan menghabiskan waktu hingga berjam-jam. ${ }^{4}$ Dalam bukunya yang berjudul "Psikologi Perkembangan: Penghantar dalam Berbagai Bagiannya”, Monk, Knoers, serta Haditono menjabarkan tentang batasan usia remaja. Mereka membedakan usia remaja menjadi empat bagian. Pertama, pra-remaja usia 10-12 tahun. Kedua, ramaja awal 12-15 tahun. Ketiga, remaja pertengahan 12-15 tahun. Keempat, remaja akhir 18-21 tahun.

Studi yang dilakukan oleh Narang dan Mathew (2012) mempublikasikan bahwa penyebab tingginya angka obesitas pada remaja yang menjadi masalah global belum dapat dimengerti secara keseluruhan. ${ }^{5}$ Beberapa pihak menyatakan faktor sosial ekonomi sebagai penyebab obesitas, sementara pihak lain menyebutkan media massa melatarbelakangi epidemi obesitas pada remaja dengan mengiklankan junk food. Inaktivitas fisik dan kurangnya keterlibatan orang tua pada pengaturan makan pun tidak bisa dilepaskan keterkaitannya dengan obesitas pada anak. Mekanisme obesitas pada remaja diduga disebabkan oleh interaksi yang kompleks antara genetik, lingkungan, sosial ekonomi, budaya, dan faktor psikologi.

Selain itu, Narang dan Mathhew juga mengatakan bahwa morbiditas yang dikaitkan dengan obesitas salah satunya meliputi hipertensi, diabetes melitus tipe 2, dislipidemia, perlemakan hati, dan gangguan tidur. ${ }^{5}$

Bersamaan dengan meningkatnya prevalens obesitas pada remaja, meningkat pula kesadaran akan gangguan tidur sebagai salah satu konsekuensi medis yang tidak jarang ditemukan pada remaja obesitas. Meningkatnya angka obesitas pada remaja dapat menimbulkan munculnya populasi berisiko baru untuk terjadinya gangguan tidur. Menurut Haryono dkk, gangguan tidur merupakan suatu kumpulan kondisi yang ditandai dengan gangguan dalam jumlah, kualitas, atau waktu tidur pada seorang individu. Timbulnya gangguan tidur tentunya akan berdampak langsung pada penurunan kualitas tidur. ${ }^{6}$

Kualitas tidur merupakan hal yang esensial, khususnya bagi remaja ataupun di antara kalangan mahasiswa yang sedang menempuh pendidikan. Mander dkk menyatakan bahwa kualitas tidur baik akan berefek pada daya ingat/memori yang lebih baik dan lama. ${ }^{7}$ Penelitian yang dilakukan oleh Nashori dkk juga menunjukkan bahwa adanya hubungan signifikan antara kualitas tidur dengan kemampuan memecahkan masalah pada mahasiswa. ${ }^{8}$ Semakin baik kualitas tidur mahasiswa, maka kemampuan mahasiswa tersebut dalam memecahkan masalah semakin baik. Sehingga, terjadinya penurunan kualitas tidur memiliki dampak serius di bidang akademis. Pada kalangan mahasiswa yang memiliki kualitas tidur buruk ditemukan prestasi akademik yang kurang baik. ${ }^{9}$ Selain prestasi akademik, risiko gangguan kesehatan lainnya juga ditemukan pada mereka dengan kualitas tidur buruk. Studi yang dilakukan oleh Moniung dkk (2014) menunjukkan bahwa kualitas tidur yang buruk berhubungan dengan terjadinya peningkatan tekanan darah. ${ }^{10}$

Araghi dkk telah menelaah hubungan kualitas tidur dengan obesitas. Mereka menyatakan bahwa hubungan keduanya bersifat bidireksional, dimana durasi tidur dan kualitas tidur memengaruhi obesitas, Sementara itu obesitas dapat pula menjadi faktor yang memengaruhi durasi dan kualitas tidur. $^{11}$

Berdasarkan latar belakang permasalahan di atas, penulis akan mengkaji pengaruh obesitas pada kualitas tidur di kalangan mahasiswa Fakultas Kedokteran Universitas Udayana di 
mana penelitian serupa belum pernah dilakukan. Pengukuran terhadap kualitas tidur melalui pengisian kuisioner Pittsburg Sleep Quality Index (PSQI). PSQI merupakan instrumen efektif yang digunakan untuk mengukur kualitas tidur dan pola tidur responden selama satu bulan terakhir. ${ }^{4}$ Selain itu pengukuran kualitas tidur menggunakan kuisioner PSQI adalah instrumen efektif yang digunakan untuk mengukur kualitas tidur berdasarkan penilaian terhadap tujuh kriteria meliputi kualitas tidur subjektif, latensi tidur, durasi tidur, efisiensi tidur, gangguan tidur, penggunaan obat tidur, dan disfungsi tidur di siang hari. Hingga saat ini, PSQI masih sering digunakan dalam penelitian yang dilaksanakan baik di dalam ataupun di luar negeri karena merupakan suatu metode yang mudah, murah dan telah sering digunakan pada berbagai penelitaian sebelumnya serta cukup akurat dalam pengukuran terhadap kualitas tidur.

\section{METODE}

Penelitian observasional jenis analitik dirancang dalam bentuk studi potong lintang (cross sectional) untuk mengetahui pengaruh kualitas tidur pada remaja obesitas. Subyek penelitian adalah mahasiswa Fakultas Kedokteran Universitas Udayana yang ditentukan dalam kelompok obesitas dan kelompok normal berdasarkan Klasifikasi Indeks Massa Tubuh menurut Kementerian Kesehatan tahun 2013 serta memenuhi kriteria inklusi sampai memenuhi jumlah sampel minimal yang diperlukan (consecutive sampling). Penelitian telah dilakukan di Fakultas Kedokteran Universitas Udayana dari bulan Juli - Desember 2018. Kriteria inklusi dalam penelitian ini adalah orang dengan obesitas, usia (indeks masa tubuh diatas $26,9 \mathrm{~kg} / \mathrm{m}^{2}$ ) dan kelompok normal dengan inedks masa tubuh 18,5 $24,9 \mathrm{~kg} / \mathrm{m}^{2}$, usia $17-22$ tahun, bersedia mengikuti pengukuran antropometri dan menandatangani inform consent. Kualitas tidur dalam penelitian ini dikaji menggunakan kuesioner PSQI. Analsisi data dalam penelitian ini menggunakan bantuan perangkat lunak SPSS versi 25.0 untuk windows. Data dilakukan analisis secara deskriptif dan uji chi-square digunakan untuk mengkaji hubungan antara kualitas tidur dengan obesitas dan juga terhadap gangguan kesehatan.

\section{HASIL}

Penelitian mengenai pengaruh obesitas pada kualitas tidur mahasiswa Fakultas Kedokteran Universitas Udayana dilaksanakan pada bulan Agustus sampai Desember 2018 setelah peneliti mendapat perizinan oleh komisi etik Fakultas Kedokteran Universitas Udayana/Rumah Sakit
Umum Pusat Sanglah untuk melakukan penelitian di Fakultas Kedokteran Universitas Udayana.

Sampel penelitian diambil dengan menggunakan kuisioner. Pada penelitian yang telah dilakukan peneliti memperoleh total sebanyak 74 sampel (37 sampel kasus dan 37 sampel kontrol). Pengambilan data yang telah dilakukan menggunakan data primer melalui pengisian kuisioner Pittsburgh Sleep Quality Index(PSQI) dengan memilah sampel secara acak yang termasuk dalam kriteria inklusi. Adapun kriteria inklusi pada penelitian ini adalah mahasiswa yang berada dalam kelompok obesitas yakni IMT di atas 26,9 dan mahasiswa dalam kelompok normal yakni IMT dalam rentang 18,5 - 24,9 dengan rentang usia 17-22 tahun. Seluruh sampel penelitian bersedia mengikuti pengukuran antropometri, pengisian kuisioner dan telah menandatangani lembar informed consent.

Berdasarkan distribusi jenis kelamin dengan Indeks Massa Tubuh didapatkan bahwa pada IMT obesitas, laki-laki sebanyak 22 sampel (52,38\%), sedangkan pada IMT obesitas, perempuan sebanyak 15 sampel (46,88\%). Pada IMT normal, lakilaki didapatkan 20 sampel (47,62\%) sedangkan IMT normal, perempuan di dapatkan 17 sampel (53,12\%) (Tabel 1).

Berdasarkan distribusi usia dengan indeks massa tubuh didapatkan bahwa pada IMT obesitas dengan usia 17 tahun didapatkan 2 sampel (100\%), IMT obesitas dengan usia 18 tahun didapatkan 4 sampel (57,14\%), IMT obesitas dengan usia 19 tahun didapatkan 17 sampel (68\%), IMT obesitas dengan usia 20 tahun didapatkan 8 sampel $(38,09 \%)$, IMT obesitas dengan usia 21 tahun didapatkan 2 sampel (15,38\%), IMT obesitas dengan usia 22 tahun didapatkan sampel $4(66,67 \%)$. Pada IMT normal dengan usia 18 tahun didapatkan 3 sampel $(42,86 \%)$, IMT normal dengan usia 19 tahun di dapatkan 8 sampel (32\%), IMT normal dengan usia 20 tahun di dapatkan 13 sampel (61,91\%), IMT normal dengan usia 21 tahun di dapatkan 11 sampel (84,62\%). IMT normal dengan usia 22 tahun didapatkan 2 sampel (33,33\%) (Tabel 2).

Dalam penelitian ini didapatkan nilai $\mathrm{p}=0,483$, sehingga dapat diketahui bahwa obesitas tidak memiliki pengaruh yang bermakna pada kualitas tidur. Pada 37 mahasiswa dengan obesitas, terdapat 22 orang dengan kualitas tidur buruk $(53,7 \%)$ dan 15 orang dengan kualitas tidur baik(45,5\%). Sementara, pada 37 mahasiswa dengan indeks massa tubuh normal, terdapat 19 orang dengan kualitas tidur buruk $(46,3 \%)$ dan 18 orang dengan kualitas tidur baik (54,5\%) (Tabel 3).

Dalam penelitian ini didapatkan nilai $\mathrm{p}=0,039$, sehingga gangguan kesehatan memiliki pengaruh yang signifikan pada kualitas tidur. Pada 20 mahasiswa dengan gangguan kesehatan, terdapat 
Tabel 1 Karakteristik berdasarkan jenis kelamin

\begin{tabular}{lccc}
\hline & \multicolumn{2}{c}{ Indeks Massa Tubuh } & \\
\cline { 2 - 3 } Jenis Kelamin & Obesitas & Normal & Total \\
\hline Laki-laki & $22(52,38 \%)$ & $20(47,62 \%)$ & $42(100 \%)$ \\
Perempuan & $15(46,88 \%)$ & $17(53,12 \%)$ & $32(100 \%)$ \\
Total & $37(50 \%)$ & $37(50 \%)$ & $74(100 \%)$ \\
\hline
\end{tabular}

Tabel 2 Karakteristik berdasarkan usia

\begin{tabular}{lccc}
\hline & \multicolumn{2}{c}{ Indeks Massa Tubuh } & \\
\cline { 2 - 3 } Usia & Obesitas & Normal & Total \\
\hline 17 tahun & $2(100 \%)$ & $0(0 \%)$ & $2(100 \%)$ \\
18 tahun & $4(57,14 \%)$ & $3(42,86 \%)$ & $7(100 \%)$ \\
19 tahun & $17(68 \%)$ & $8(32 \%)$ & $25(100 \%)$ \\
20 tahun & $8(38,09 \%)$ & $13(61,91 \%)$ & $21(100 \%)$ \\
21 tahun & $2(15,38 \%)$ & $11(84,62 \%)$ & $13(100 \%)$ \\
22 tahun & $4(66,67 \%)$ & $2(33,33 \%)$ & $6(100 \%)$ \\
Total & $37(50 \%)$ & $37(50 \%)$ & $74(100 \%)$ \\
\hline
\end{tabular}

Tabel 3 Pengaruh obesitas pada kualitas tidur

\begin{tabular}{lcccc}
\hline & \multicolumn{2}{c}{ Indeks Massa Tubuh } & & \\
\cline { 2 - 3 } Kualitas Tidur & Obesitas & Normal & Total & $\boldsymbol{p}$ \\
\hline Buruk & $22(53,7 \%)$ & $19(46,3 \%)$ & $41(100 \%)$ & 0,483 \\
Baik & $15(45,5 \%)$ & $18(54,5 \%)$ & $33(100 \%)$ & \\
Total & $37(50 \%)$ & $37(50 \%)$ & $74(100 \%)$ & \\
\hline
\end{tabular}

Tabel 4 Pengaruh gangguan kesehatan pada kualitas tidur

\begin{tabular}{|c|c|c|c|c|}
\hline \multirow[b]{2}{*}{ Kualitas Tidur } & \multicolumn{2}{|c|}{ Gangguan Kesehatan } & \multirow[b]{2}{*}{ Total } & \multirow[b]{2}{*}{$p$} \\
\hline & Ada & Tidak ada & & \\
\hline Buruk & $15(36,6 \%)$ & $26(63,4 \%)$ & $41(100 \%)$ & \multirow{3}{*}{0,039} \\
\hline Baik & $5(15,2 \%)$ & $28(84,8 \%)$ & $33(100 \%)$ & \\
\hline Total & $20(27 \%)$ & $54(73 \%)$ & $74(100 \%)$ & \\
\hline
\end{tabular}

15 orang dengan kualitas tidur buruk(36,6\%) dan 5 orang dengan kualitas tidur baik $(15,2 \%)$. Sementara, pada 54 mahasiswa dengan indeks massa tubuh normal, terdapat 26 orang dengan kualitas tidur buruk $(63,4 \%)$ dan 28 orang dengan kualitas tidur baik (84,8\%) (Tabel 4).

\section{PEMBAHASAN}

Orang dengan obesitas memiliki frekuensi gangguan tidur lebih tinggi dibandingan kelompok orang yang sehat. ${ }^{12}$ Hal ini menyebabkan obesitas memicu terjadinya durasi tidur yang lebih singkat dan perolehan skor PSQI yang lebih tinggi. ${ }^{13}$ Dengan perolehan skor PSQI yang lebih tinggi dibandingkan kelompok non-obese, obesitas memiliki pengaruh yang signifikan terhadap kualitas tidur yang buruk. Namun, dalam penelitian ini, penulis tidak menjumpai hal serupa. Pada penelitian ini, obesitas tidak memiliki pengaruh yang bermakna pada kualitas tidur $(\mathrm{p}=0,483)$, sehingga hipotesis penulis tidak terbukti. Di sisi lain, dalam studi yang dilakukan oleh penulis, terdapat hubungan antara gangguan kesehatan terhadap kualitas kesehatan $(\mathrm{p}=0,039)$.

Hasil penelitian yang menunjukkan bahwa obesitas tidak memiliki pengaruh terhadap kualitas tidur sejalan dengan penelitian yang sebelumnya dilakukan oleh Hasiana dkk yang menjumpai tidak ada hubungan bermakna antara indeks massa tubuh dan kualitas tidur di kalangan mahasiswa. ${ }^{14}$ Hal ini juga sesuai dengan penelitian di Turki yang dilakukan oleh Öztürk dkk di mana tidak ada relasi bermakna antara indeks massa tubuh, ketebalan lipatan kulit pada triceps, lingkar pinggang, massa lemak tubuh, rasio lemak tubuh (\%) dengan kualitas tidur $(\mathrm{p}>0.05) .{ }^{15}$ Namun, pada peneilitian tersebut turut mengevaluasi jenis makanan yang dikonsumsi oleh respondennya. Hasil yang diperoleh adalah semakin tinggi konsumsi roti secara signifikan berhubungan dengan kualitas tidur yang rendah $(\mathrm{p}<0,05)$.

Sehubungan dengan jenis makanan yang dikonsumsi, Yoneyamai dkk mengungkapkan bahwa responden dengan konsumsi beras yang tinggi memiliki kualitas tidur yang baik, dan responden dengan konsumsi mi yang tinggi berkorelasi dengan kualitas tidur yang buruk. ${ }^{16}$ Studi yang dilakukan oleh St-Onge dkk menyatakan bahwa beberapa makanan seperti konsumsi susu, ikan, buah-buahan serta sayuran dapat memberikan efek yang mempromosikan tidur. ${ }^{17}$ Penelitian yang dilakukan oleh penulis di Fakultas Kedokteran Universitas Udayana diikuti oleh mahasiswa dengan jenis kelamin berbeda serta latar belakang kebudayaan yang beranekaragam. Jenis kelamin perempuan memiliki kecendrungan untuk memiliki kebiasaan mengonsumsi camilan lebih tinggi dibandingkan jenis kelamin laki-laki. ${ }^{18}$ Pada remaja laki-laki terdapat pola konsumsi sayur yang kurang sebesar 2,498 kali lebih besar dibandingkan remaja perempuan. ${ }^{19}$ Jenis makanan yang dipilih oleh seseorang juga tak lepas dari kebiasaan makan yang telah terbentuk sejak dahulu dan sebagai hasil dari kebudayaan di daerah asal masing-masing orang. Sehubungan dengan studi kali ini, berbagai faktor tersebut akan secara signifikan menimbulkan keanekragaman jenis makanan yang dikonsumsi mahasiswa serta turut mempengaruhi kualitas tidur.

Selain itu, pada kawasan Fakultas Kedokteran Universitas Udayana dapat dengan mudah dijumpai vending machine (mesin penjual minuman otomatis) yang menyajikan minuman yang mengandung 
kafein. Bahkan di areal kantin Fakultas Kedokteran Universitas Udayana, terdapat beberapa stan yang khusus menjual minuman kopi serta teh dengan segala variannya. Saat penelitian ini berlangsung, tren meminum kopi di kalangan anak muda juga sedang marak diperbincangkan. Sebagai antagonis reseptor adenosinergik, kafein yang terkandung di dalam teh dan kopi merupakan substansi psikoaktif yang paling awam dikenal di masyarakat serta paling banyak dikonsumsi untuk mengembalikan tingkat kesadaran yang rendah, memodulasi aktivitas otak, serta mampu meningkatkan performa pribadi. Sehingga konsumsi minuman yang mengandung kafein memiliki pengaruh kuat terhadap kualitas tidur mahasiswa.

Penelitian yang dilakukan oleh penulis menjumpai fakta bahwa sampel dengan kualitas tidur buruk terdapat gangguan kesehatan meliputi asam urat, demam, flu, batuk, alergi, jantung berdebar, kesemutan, sakit kepala, radang tenggorokan, otitis media, dan gangguan pencernaan (diare dan maag). Gangguan kesehatan ini menyebabkan terjadinya penurunan pada dimensi kualitas tidur subjektif, durasi tidur, serta efisiensi kebiasaan tidur. Di sisi lain, gangguan kesehatan tersebut menyebabkan peningkatan latensi tidur, gangguan tidur, serta terjadinya disfungsi aktivitas siang hari. Berbagai faktor tersebut menyebabkan mahasiswa dengan gangguan kesehatan memiliki kualitas tidur yang buruk.

Teknologi elektronik juga turut memainkan peran terhadap kualitas tidur mahasiswa. Seiring sumber informasi, media sosial dan sarana hiburan yang telah berkembang dengan pesat diikuti tanggung jawab penyelesaian tugas dari kampus, media elektronik telah menjadi kebutuhan wajib dan memiliki tempat yang tak tergantikan di kalangan mahasiswa. Sebuah studi menyatakan bahwa akan timbul kesulitan seseorang untuk memulai tidur bila terdapat pengoperasian perangkat teknologi beberapa saat sebelum beristirahat. ${ }^{21} \mathrm{Hal}$ ini disebabkan karena selama pemakaiannya terdapat rangsangan kognitif dan fisiologis yang mampu mengambat inisiasi tidur normal. ${ }^{22}$ Penelitian yang dilakukan Khan $\mathrm{dkk}^{20}$ menyatakan bahwa pada mahasiswa yang sesaat sebelum beristirahat mengonsumsi hiburan atau melakukan interaksi via perangkat eletronik lebih dari 4 kali tiap minggu memiliki kecendrungan lebih besar untuk mengalami latensi tidur lebih dari 1 jam dibandingkan dengan mereka yang menggunakan perangkat tersebut $\leq 3$ kali. Pada paparan layar komputer dengan pencahayaan LED di malam hari juga telah dibuktikan mampu menganggu siklus tidur normal dan menekan melatonin. ${ }^{23,24}$

Beberapa faktor yang mungkin mempengaruhi kualitas tidur mahasiswa Fakultas Kedokteran
Universitas Udayana dan tidak diteliti oleh penulis adalah tingkat stress dan kecemasan. Studi ini dilaksanakan pada mahasiswa di beberapa semester dan $t$ iap mahasiswa memiliki tingkat stress serta kecemasan yang berbeda. Selain itu, studi ini dilaksanakan pada saat jam aktif pembelajaran di mana aktivitas mahasiswa diisi dengan berbagai kewajiban tugas belajar, pengumpulan tugas, dan persiapan ujian. Baik tingkat tress dan kecemasan, keduanya memiliki peranan penting dalam menentukan kualitas tidur seseorang.

Keterbatasan dalam penelitian ini adalah rancangan cross-sectional serta jumlah sampel yang kecil menyebabkan nilai kausal terhadap obesitas dan gangguan tidur menjadi rendah. Hal ini juga mempengaruhi generalisasi hasil penelitian ke populasi umum.

\section{SIMPULAN}

Berdasarkan hasil penelitian di atas, disimpulkan bahwa obesitas tidak memiliki pengaruh signifikan terhadap kualitas tidur mahasiswa Fakultas Kedokteran Universitas Udayana. Hal ini disebabkan oleh beberapa faktor seperti tingkat stress dan kecemasan di kalangan mahasiswa, jenis makanan dan minuman yang dikonsumsi serta frekuensi pemakaian teknologi sesaat sebelum beristirahat turut mempengaruhi kualitas tidur. Namun, beberapa faktor tersebut tidak dikontrol dalam penelitian ini. Secara khusus dalam penelitian kali ini dijumpai adanya gangguan kesehatan yang turut mempengaruhi kualitas tidur mahasiswa Fakultas Kedokteran Universitas Udayana.

\section{KONFLIK KEPENTINGAN}

Penulis menyatakan tidak terdapat suatu konflik kepentingan terkait publikasi dari artikel ini.

\section{PENDANAAN}

Penelitian ini tidak mendapatkan pendanaan dari pemerintah ataupub lembaga swasta lain.

\section{ETIKA DALAM PENELITIAN}

Penelitian ini telah mendapat persetujuan Komite Etik Fakultas Kedokteran Universitas Udayana/ RSUP Sanglah Denpasar dengan nomer referensi 1799/UN14.2.2.VII.14/LP/2018

\section{DAFTAR PUSTAKA}

1. Suastika K. Endokrinologi \& Pendidikan Tinggi Edisi 1. Denpasar: Udayana University Press; 2009. p. 65-70. 
2. World Health Organization. Health topic :Obesity [Internet]. Geneva: WHO; 2016 [Diakses 20 Juli 2016]. Tersedia di: http://www.who.int/topics/obesity/en/.

3. Ogden CL, Carroll, MD, Kit BK, Flegal KM. Prevalence of Childhood and Adult Obesity in the United States, 2011-2012. Journal of the American Medical Association. 2014;311(8):806-14.

4. Gupta NK, Mueller WH, Chan W, Meininger JC. Is obesity associated with poor sleep quality in adolescents? Am J Hum Biol. 2002;14:762-8.

5. Narang I, Mathew JL. Childhood Obesity and Obstructive Sleep Apnea. Journal of Nutrition and Metabolism. 2012:134202. doi: 10.1155/2012/134202

6. Haryono A, Rindiarti A, Arianti A, Pawitri A, Ushuluddin U, Setiawati A, Reza A, Wawolumaja CW, Sekartini R. Prevalensi Gangguan Tidur pada Remaja Usia 12-15 Tahun di Sekolah Lanjutan Tingkat Pertama. Sari Pediatri. 2009;11(3):149-54.

7. Mander B, Walker M. Kualitas tidur dan usia mempengaruhi tugas mengingat otak [Internet]. Jakarta: Mediapubli; 2009 (Diakses 21 Februari 2014). Tersedia di: http://www.Mediapubli ca.co.

8. Nashori F. Mencapai puncak prestasi dengan meningkatkan kualitas tidur dan mimpi: perspektif psikologi Islam [Internet]. Jakarta: UAD; 2010 (Diakses 21 Februari 2014). Tersedia di: http://www. journal.uad .ac.id.

9. Nilifda H, Nadjmir H. Hubungan Kualitas Tidur Dengan Prestasi Akademik Mahasiswa Program Studi Pendidikan Dokter Angkatan 2010 Fakultas Kedokteran Universitas Andalas. Jurnal Kesehatan Andalas. 2016;5(1):243-249.

10. Moniung, Rondonuwu, dan Bataha. (2014). Hubungan Tekanan Darah Sistolik Dengan Kualitas Tidur Pasien Hipertensi di Puskesmas Bahu. Jurnal Keperawatan. 2014;2(2):1-8.

11. Araghi $\mathrm{MH}$, Jagielski A, Neira I, Brown A, Higgs S, Thomas GN, Taheri S. The Complex Associations Among Sleep Quality, Anxiety-Depression, and Quality of Life in Patients with Extreme Obesity. SLEEP. 2013;36(12):1859-1865.

12. Algul A, Ates MA, Semiz UB. Evaluation of general psychopathology, subjective sleep quality, and health-related quality of life in patients with obesity. Int J Psychiatry Med. 2009;39:297-312.

13. Toor P, Kim K, Buffington CK. Sleep quality and duration before and after bariatric surgery. Obes Surg. 2012;22:890-5.

14. Hasiana RD. Hubungan Pola Tidur dengan Indeks Massa Tubuh pada Mahasiswa Fakultas Kedokteran Universitas Sumatera Utara Angkatan 2010, 2011, dan 2012 [Skripsi]. Medan: Universitas Sumatera Utara; 2013.

15. Öztürk ME, \& Yabanc1 AN. Associations between Poor Sleep Quality, Obesity, and the Anthropometric Measurements of Women in Turkey. Ecology of Food and Nutrition. 2017;57(1):3-12.

16. Yoneyamai SM, Sakura1 K, Nakamura Y, Morıkawa K, Miura M, Nakashıma K, Yoshıta M, Ishızakı TK, Naruse Y. Associations between rice, noodle, and bread intake and sleep quality in Japanese men and women. PloS One. 2014;9(8):e105198.

17. St-Onge MP, Mikic A, Pietrolungo CE. Effects of Diet on Sleep Quality. Advances in Nutrition. 2016;7(5):938-949.

18. Saufika A. Pengaruh gaya hidup terhadap kebiasaan makan mahasiswa [Skripsi]. Bogor : Departemen Ilmu Keluarga Dan Konsumen Fakultas Ekologi Manusia Institut Pertanian Bogor; 2012.

19. Sianturi U. Faktor-Faktor yang Berhubungan dengan Konsumsi Sayur dan Buah pada Remaja yang Tinggal di Rumah Kos di Kota TarutungTahun 2017 [Tesis]. Sumetera Utara : Fakultas Kesehatan Masyarakat Universitas Sumatera Utara; 2018

20. Khan F, Haroon H, Murtaza H, Anwar E. Determinants of Sleep Quality among Undergraduate Students of Universities of Karachi. Annals of Psychophysiology. 2016;3. 04. 10.29052/2412-3188.v3.i1.2016.4-13.

21. Gradisar M, Wolfson AR, Harvey AG, Hale L, Rosenberg R, Czeisler CA. The sleep and technology use of Americans: findings from the National Sleep Foundation's 2011 Sleep in America poll. J Clin Sleep Med. 2013;9(12):1291-1299.

22. Ivarsson $\mathrm{M}$, Anderson $\mathrm{M}$, Åkerstedt $\mathrm{T}$, Lindblad $\mathrm{F}$. Playing a violent television game affects heart rate variability. Acta paediatrica. 2009;98(1):166-172

23. Cajochen C, Frey S, Anders D, Spati J, Bues M, Pross A, Stefani O. Evening exposure to a light-emitting diodes (LED)-backlit computer screen affects circadian physiology and cognitive performance. J Appl Physiol. 2011;110(5):14321438

24. Dehghanmehr S, Shadadi H, Mansouri A, Arbabisarjou A. Effect of oral saffron capsules on sleep quality in patients with diabetes at Zabol-Iran. Bali Medical Journal. 2017;6(3): 595-600. DOI:10.15562/bmj.v6i3.623.

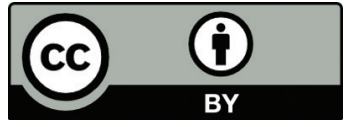

This work is licensed under a Creative Commons Attribution 